\title{
SISTEM PAKAR DIAGNOSA HAMA DAN PENYAKIT PADA TANAMAN CABAI BERBASIS WEBSITE
}

\author{
Cipta Riang Sari ${ }^{1}$, Muammar ${ }^{2}$ \\ 1,2Program Studi Sistem Informasi, Universitas Al Asyariah Mandar \\ e-mail: ciptariangsari@unasman.ac.id ${ }^{1}$, muammar@unasman.ac.id ${ }^{2}$
}

\begin{abstract}
Abstrak
Cabai merupakan salah satu tanaman di bidang pertanian yang banyak di budidayakan di Indonesia yang memiliki bebrapa masalah, satu masalah yang sering dihadapi oleh petani cabai adalah kurangnya pengetahuan tentang hama dan penyakit yang menyerang tanamannya. Terbatasnya jumlah pakar yang ada mengakibatkan petani mengalami kesulitan untuk berkonsultasi dengan pakar jika sewaktu- waktu tanaman cabai mereka diserang oleh hama dan penyakit. Penelitian ini bertujuan Membangun sistem pakar untuk mendiagnosa hama dan penyakit pada tanaman cabai yang berbasis website menggunakan metode Forward Chaining dan Certainty Factor. Solusi dari permasalahan tersebut adalah dengan merancang perangkat lunak system pakar menggunakan metode Forward Chaining sebagai proses pelacakan sedangkan metode Certainty Factor merupakan cara untuk membuktikan apakah suatu fakta itu pasti ataukah tidak pasti, dengan sistem tersebut mampu melakukan diagnosa hama dan penyakit pada tanaman cabai berdasarkan gejala-gejala yang diberikan. Berdasarkan hasil perhitungan, maka keterangan tingkat keyakinan berdasarkan tabel interpretasi dari pakar dan persentase akhir sebesar 83,1\% adalah Sangat Mungkin kedua metode ini diterapkan untuk menyelesaikan masalah yang ada. Sistem ini dibangun untuk menyimpan keahliah seorang pakar hama dan penyakit pada tanaman cabai, sehingga sistem ini dapat dijadikan asisten pandai dibidang pertanian sebagai sumber pengetahuan user.
\end{abstract}

Kata kunci : Forward Chaining; Certainty Factor; Tanaman Cabai

\begin{abstract}
Chili is one of the crops in agriculture that widely cultivated in Indonesia which has several problems, one problem that is often faced by chili farmers a lack of knowledge about pests and diseases that attack their plants. The limited number of experts available makes it difficult for farmers to consult with experts if any time their chili plants are attacked by pests and diseases. This study aims to build an expert system to diagnose pests and diseases in website-based chili plants using Forward Chaining and Certainty Factor methods. The solution to this problem is to design expert system software using the Forward Chaining is a tracking process while the Certainty Factor method is a way to prove whether a fact is certain or uncertain, with the system being able to diagnose pests and diseases in chili plants based on the symptoms given. Based on the results of the calculation, the information on the level of confidence based on the interpretation table from the expert and the final percentage of $83.1 \%$ is very likely that these two methods are applied to solve the existing problem. This system was built to save the expertise of an expert on pests and diseases in chili plants, so that this system can be used as a smart assistant in agriculture as a source of user knowledge.
\end{abstract}

Keywords : Forward Chaining; Certainty Factor; Chili Plant 
I

PENDAHULUAN

Indonesia adalah salah satu negara yang memiliki jumlah petani hampir setengah dari jumlah penduduknya. Salah satu tanaman yang dibudidayakan petani Indonesia adalah cabai merah. Menanam cabai telah dijadikan sebagai mata pencaharian dari sebagian petani di Indonesia. Tetapi masih banyak dari petani yang belum dapat menanam tanaman cabai sesuai dengan standar yang ada, dan bisa mengakibatkan terserangnya tanaman oleh hama dan penyakit, kebanyakan tidak mengetahui dengan jelas jenis penyakit dan hama yang sedang menyerang cabai. Kebanyakan petani akan menerka-nerka penyakit apa yang sedang menyerang tanaman cabainya dan mencoba alternatif pengobatan yang belum jelas hasilnya sehingga akan mengakibatkan para petani merugi, karena tanamannya mati, harga jual yang rendah dan hasil panen yang sedikit. Sehingga petani membutuhkan pengetahuan dari pakar untuk meningkatkan kualitas dalam menanam dan juga meningkatkan harga jual tanaman cabai.

Sistem Pakar (Expert System) adalah program berbasis pengetahuan yang menyediakan solusi-solusi dengan kualitas pakar untuk problema-problema dalam suatu domain yang spesifik. Sistem Pakar merupakan program komputer yang meniru proses pemikiran dan pengetahuan pakar dalam menyelesaikan suatu masalah tertentu. Salah satu implementasi yang diterapkan sistem pakar dalam bidang pertanian [1].

Media yang dapat membantu permasalahan diatas adalah dengan dibuatnya Sistem Pakar Diagnosa Hama dan Penyakit Tanaman Cabai Besar. Pada penelitian ini metode Certainty Factor diterapkan untuk mengakomodasi tingkat keyakinan pakar sehingga dapat diterapkan untuk membuat Sistem Pakar Diagnosa Hama dan Penyakit Tanaman Cabai Besar
Menggunakan Metode Certainty Factor dan didapatkan presentase nilai keyakinan serangan hama atau penyakit beserta solusi pengendaliannya [2]. Cara untuk mengatasi permasalahan ketidakpastian dengan mengguanakan metode Dempster-Shafer, dieksekusi. Setelah aturan yang cocok dieksekusi maka akan ada fakta baru pada bagian THEN akan ditambahkan dalam basis data. Pencocokan dimulai dari aturan paling atas dan setiap aturan hanya bias dieksekusi satu kali [3].

\section{TINJAUAN PUSTAKA}

\subsection{Sistem Pakar}

Sistem pakar adalah aplikasi berbasis komputer untuk menyelesaikan suatu masalah seahri-hari sebagaimana halnya seperti yang dilakukan oleh seorang pakar [4].

Struktur sistem pakar terdari: basis pengetahuan, mesin inferensi, basis data dan antarmuka pemakai [5].

\subsection{Basis Pengetahuan}

Basis pengetahuan merupakan inti dari suatu sistem pakar, yaitu berupa representasi pengetahuan dari pakar. Basis pengetahuan tersusun atas fakta dan kaidah. Fakta adalah informasi tentang objek, peristiwa, atau situasi. Kaidah adalah cara untuk membangkitkan suatu fakta baru dari fakta yang sudah diketahui. Basis pengetahuan merupakan representasi dari seorang pakar, yang kemudian dapat dimasukkan kedalam bahasa pemrograman khusus untuk kecerdasan buatan (misalnya PROLOG atau $P H P$ ).

\subsection{Mesin Inferensi}

Mesin inferensi berperan sebagai otak dari sistem pakar. Mesin inferensi berfungsi untuk memandu proses penalaran terhadap suatu kondisi, berdasarkan pada basis pengetahuan yang tersedia. 


\subsection{Antarmuka Pengguna (User Interface)}

User interface merupakan mekanisme yang digunakan oleh pengguna dan sistem pakar untuk berkomunikasi.

\subsection{Metode-metode Pada Sistem Pakar}

Adamun metode-metode yang biasa digunakan dalam pembuatan sebuah sistem pakar yaitu sebagai berikut:

1 Metode Bayes

Metode Bayes adalah salah satu metode untuk mengatasi ketidakpastian suatu data, yang kemudian dapat dirumuskan dalam persamaan bayes sebagai berikut [6]

$$
P(H \mid E)=\frac{P(E \mid H) \cdot P(H)}{P(E)}
$$

Keterangan :

$\mathrm{P}(\mathrm{H} \mid \mathrm{E})$ : Probabilitas hipotesa $\mathrm{H}$ jika diketahui evidence $\mathrm{E}$.

$\mathrm{P}(\mathrm{E} \mid \mathrm{H}) \quad$ : Probabilitas munculnya evidence $E$ jika diketahui hipotesa $\mathrm{H}$.

$\mathrm{P}(\mathrm{H}) \quad$ : Probabilitas hipotesa $\mathrm{H}$.

$\mathrm{P}(\mathrm{E}) \quad$ : Probabilitas evidence $\mathrm{E}$

\section{Metode Breadth First Search (BFS)}

Metode Breadth First Search (BFS) merupakan pencarian yang dilakukan dengan mengunjungi tiap-tiap node secara sistematis pada setiap level hingga keadaan tujuan (goal state) ditemukan. Dengan kata lain menggunjungi terlebih dahulu semua node yang selevel hingga ditemukan goal statenya. Breadth First Search dapat diartikan juga dengan algoritma pencarian simpul dalam graf (pohon) secara travelsal yang dimulai dari simpul akar dan mengecek semua simpul-simpul tetangganya. Setelah itu, dari tiap simpul tetangganya, algoritma akan terus mencek semua simpul tetangganya yang belum dicek, sedemikian seterusnya hingga menemukan simpul tujuan Breadt First Search. Interpreter kaidah mulai dari fakta yang ada yaitu hipotesa kemudian kaidah bagian THEN mulai di uji untuk mendukung hipotesa awal. Jika ditemukan maka kaidah $I F$ yang cocok digunakan untuk menghasilkan hipotesa antara yang baru. Kemudian proses berantai terus di ulang, mengumpulkan bukti yang mendukung, sehingga hipotesa terbukti kebenarannya [7].

\section{$3 \quad$ Metode Depth Frist Search (DFS)}

Merupakan teknik penelusuran data pada node-node secara vertikal dan mendalam. Pencarian dilakukan pada satu node dalam setiap level dari yang paling kiri. Jika pada level yang paling dalam, solusi belum ditemukan maka pencarian dilanjutkan pada node sebelah kanan. Node yang kiri dapat dihapus dari memori. Jika pada level dalam tidak ditemukan solusi maka pencarian dilanjutkan pada level sebelumnya. Demikian seterusnya sampai ditemukan solusi. Jika solusi ditemukan maka tidak diperlukan proses backtracking (penelusuran balik untuk mendapatkan jalur yang diinginkan [8].

\section{Metode Backward Chaining (BF)}

Metode Backward-Chaining, sesuai namanya bekerja mundur dari query-nya. Jika query q diketahui adalah benar, maka tak ada yang perlu dikerjakan selanjutnya. Selain itu, algoritmanya akan mencari implikasi-implikasi di dalam basis data pengetahuan atau Knowledge Base (KB) yang kesimpulannya adalah q. Jika semua premis-premis dari salah satu implikasiimplikasi tersebut bisa dibuktikan benar, maka q adalah benar. Jelas sekali disini bahwa backward-chaining menggunakan algoritma pencarian depth-first. Backwardchaining adalah sebuah bentuk pemikiran yang dikendalikan oleh tujuan atau goal. Backward-chaining berguna untuk menjawab pertanyaan-pertanyaan yang spesifik seperti "Apa yang harus aku lakukan sekarang?" dan "Dimana kunci- 
kunci ku?". Seringkali, harga dari metode backward-chaining lebih sedikit dari pada pencarian linear didalam KB, karena prosesnya hanya menyentuh fakta-fakta yang terkai [9].

\subsection{Ranut Maju (Forward Chaining)}

Forward chaining digunakan untuk mengungkapkan fakta dan kesimpulan (conclusion) serta sebagai strategi inference yang berawal dari sejumlah data. Pencarian dilakukan menggunakan rules yang premisnya cocok dengan fakta yang diketahui tersebut untuk mendapatkan fakta yang baru dan melakukan proses sampai tidak ada lagi rules yang premisnya cocok dengan fakta yg ada sebelumnya [8]

Forward chaining dimulai dari premis- premis atau dari informasi masukan (if) dan kemudian menuju ke konklusi atau derived information (then). Metode ini dapat menyelesaikan masalah pengendalian (controlling) dan peramalan (prognosis) [2]

Forward chaining akan digunakan apabila Banyak aturan yang berbeda tetapi memiliki kesimpulan yang sama selain itu, memiliki Banyak cara untuk mendapatkan sedikit konklusi dan Benar-benar telah mendapatkan berbagai fakta, dan ingin mendapatkan konklusi dari beberapa fakta tersebut.

\subsection{Faktor Kepastian (Certainty Factor) \\ Certainty Factor merupakan suatu} metode untuk membuktikan ketidakpastian pemikiran seorang pakar, dimana untuk mengakomodasi hal tersebut seseorang biasanya menggunakan certainty factor untuk menggambarkan tingkat keyakinan pakar terhadap masalah yang sedang dihadapi [2]

\subsection{Diagnosa}

Diagnosa merupakan identifikasi jenis penyakit dengan cara mengamati gejala- gejalanya. Konsep diagnosa Selain identifikasi juga mengimplikasikan suatu upaya untuk meramalkan kemungkinan dan menyarankan tindakan pemecahannya [6].

\subsection{Penelitian Terdahulu}

Diagnosa penyakit pada tanaman rumput laut, dengan menggunakan metode certainty factor dan forward chaining berbasis web, yang dilakukan di Kabupaten Aru dengan hasil penelitian sistem pakar diagnosa penyakit pada tanaman rumput laut mengunakan metode forwad chaining dan certainty factor berbasis web ini, mampu mengidentifikasikan gejala dan penyakit serta memberikan solusi atau penanganan yang tepat [2].

Penelitian yang lain adalah penelitian yang dilakukan [2]. Melakukan penelitan tentang Penerapan Metode Forward Chaining Dan Certainty Factor Pada Sistem Pakar Diagnosa Hama Anggrek Coelogyne Pandurata, yang dilakukan di Yogyakarta dengan hasil penelitian Metode Forward Chaining dan Certanty Factor dapat memberikan diagnosa hama pada Anggrek Coelogyne Pandurata berdasarkan gejalagejala yang diberikan Berdasarkan hasil perhitungan, maka keterangan tingkat keyakinan berdasarkan tabel interpretasi dari pakar dan persentase akhir sebesar 93,0736\% adalah Sangat Mungkin kedua metode ini diterapkan ntuk menyelesaikan masalah yang ada.

\section{METODOLOGI PENELITIAN}

Kerangka sistem merupakan siklus umum untuk menggambarkan tujuan yang ingin dicapai. Kerangka sistem memuat input, proses dan output dari penelitian. Maka kerangka sistem dalam mencapai tujuan penelitian ini maka akan disajikan pada gambar 1 


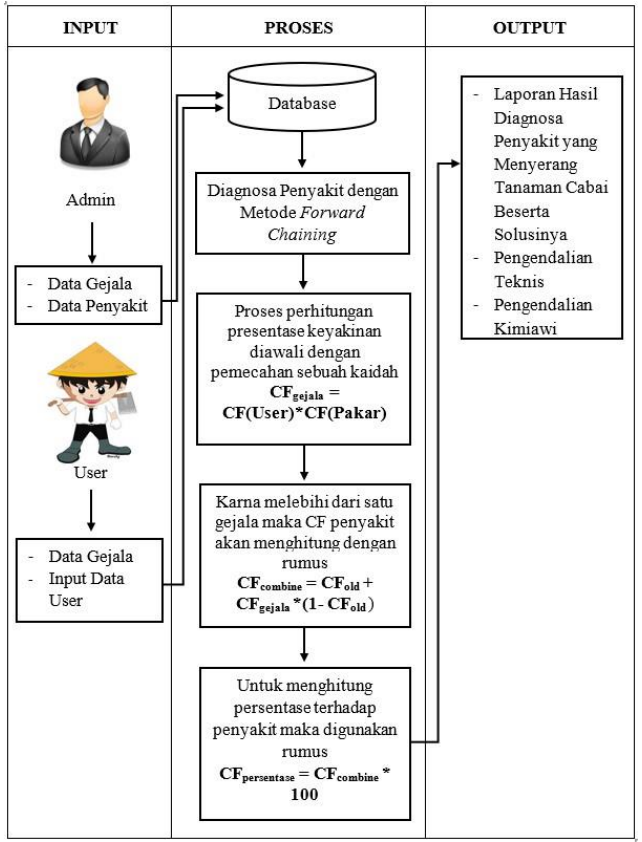

Gambar 1. Kerangka Sistem

Untuk memperoleh gambaran mengenai data yang dibutuhkan dalam penelitian ini digunakan teknik pengumpulan data sebagai berikut:

\section{Studi pustaka}

Tahapan pengumpulan data selanjutnya pada penelitian ini yaitu melalui studi pustaka dengan mengumpulkan data dan informasi dari buku, website dan jurnal yang terkait dengan pokok bahasan penelitian ini 2 Observasi

Melakukan pengamatan secara langsung kelapangan dengan melihar proses kegiatan yang berhubungan dengan perencanaan sistem pakar yang akan dibuat.

\section{Wawancara}

Pengumpulan data yang dilakukan dengan cara mewancari langsung pakar tanaman cabai dan petani cabai.

\subsection{Metode Pengembangan Sistem}

Metode pengembangan sistem yang digunakan adalah Backward Chaining dan Forward Chaining

$1 \quad$ Metode Backward Chaining (BF)

Metode Backward-Chaining, sesuai namanya bekerja mundur dari query-nya. Jika query q diketahui adalah benar, maka tak ada yang perlu dikerjakan selanjutnya.

2 Forward chaining

Forward chaining adalah sebuah penalaran yang diawali dengan fakta untuk mendapatkan sebuah kesimpulan (conclusion) dari fakta tersebut.

3 Perhitungan Manual Dalam Metode Certainty Factor

Pada sesi diagnosa penyakit, user diberikan pilihan interpretasi yang masing- masing memiliki nilai $C F$ sebagai berikut [9]:

Tabel 1. Tabel Rule (Aturan)

\begin{tabular}{|c|l|}
\hline NO & \multicolumn{1}{|c|}{ Rule } \\
\hline 1 & $\begin{array}{l}\text { If [G010] And [G011] And [G012] } \\
\text { Then S4 }\end{array}$ \\
\hline
\end{tabular}

Tabel 2. Nilai Bobot User

\begin{tabular}{|c|c|l|c|}
\hline NO & $\begin{array}{c}\text { Kode } \\
\text { Gejala }\end{array}$ & $\begin{array}{c}\text { Nama } \\
\text { Gejala }\end{array}$ & $\begin{array}{c}\text { Nilai Bobot } \\
\text { Pengguna }\end{array}$ \\
\hline \multirow{2}{*}{1} & G01 & $\begin{array}{l}\text { Daun } \\
\text { Menguning } \\
\text { sebelum } \\
\text { Waktunya } \\
\text { dan } \\
\text { berguguran } \\
\text { yang } \\
\text { tinggal } \\
\text { buah dan } \\
\text { ranting } \\
\text { saja. }\end{array}$ & \\
\hline
\end{tabular}




\begin{tabular}{|c|l|l|l|}
\hline \multirow{2}{*}{2} & G02 & $\begin{array}{l}\text { Pusat } \\
\text { bercak } \\
\text { berwarna } \\
\text { pucat pada } \\
\text { daun } \\
\text { dengan } \\
\text { warna tepi } \\
\text { lebih tua. }\end{array}$ & 0.2 \\
\hline 3 & G03 & $\begin{array}{l}\text { Daun } \\
\text { terdapat } \\
\text { bercak } \\
\text { kecil } \\
\text { berbentuk } \\
\text { bulat dan } \\
\text { kering. }\end{array}$ & \\
\hline
\end{tabular}

Tabel 3. Nilai Bobot Pakar

\begin{tabular}{|c|c|l|c|}
\hline NO & $\begin{array}{c}\text { Kode } \\
\text { Gejala }\end{array}$ & Nama Gejala & $\begin{array}{c}\text { Nilai } \\
\text { Bobot } \\
\text { Pakar }\end{array}$ \\
\hline 1 & G01 & $\begin{array}{l}\text { Denguning } \\
\text { sebelum } \\
\text { Waktunya dan } \\
\text { berguguran yang } \\
\text { tinggal buah dan } \\
\text { ranting saja. }\end{array}$ & 0.7 \\
\hline 2 & G02 & $\begin{array}{l}\text { Pusat bercak } \\
\text { berwarna pucat } \\
\text { pada daun } \\
\text { dengan warna } \\
\text { tepi lebih tua. }\end{array}$ & 0.8 \\
\hline 3 & G03 & $\begin{array}{l}\text { Daun terdapat } \\
\text { bercak kecil } \\
\text { berbentuk bulat } \\
\text { dan kering. }\end{array}$ & 0.9 \\
\hline
\end{tabular}

Tabel 4. Nilai Evidence Tingkat

\begin{tabular}{|l|l|l|l|}
\hline Tidak & $=$ & 0.0 & Tidak \\
\hline $\begin{array}{l}\text { Ragu- } \\
\text { Ragu }\end{array}$ & $=$ & 0.2 & $\begin{array}{l}\text { Ragu- } \\
\text { Ragu }\end{array}$ \\
\hline Mungkin & $=$ & 0.4 & Mungkin \\
\hline $\begin{array}{l}\text { Sangat } \\
\text { Mungkin }\end{array}$ & $=$ & 0.6 & $\begin{array}{l}\text { Sangat } \\
\text { Mungkin }\end{array}$ \\
\hline
\end{tabular}

\begin{tabular}{|l|l|l|l|}
\hline $\begin{array}{l}\text { Hampir } \\
\text { Pasti }\end{array}$ & $=$ & 0.8 & $\begin{array}{l}\text { Hampir } \\
\text { Pasti }\end{array}$ \\
\hline Pasti & $=$ & 1.0 & Pasti \\
\hline
\end{tabular}

Proses perhitungan prosentasi keyakinan diawali dengan pemecahan sebuah kaidah (rule) yang memiliki gejala majemuk, menjadi kaidah-kaidah (rules) yang memiliki gejala tunggal. Kemudian masing-masing rule baru dihitung $C F$ nya dengan menggunakan persamaan 2.2:

\section{$\mathbf{C F}_{\text {gejala }}=\mathbf{C F}($ user $) * \mathbf{C F}($ pakar $)$}

Namun apabila terdapat lebih dari satu gejala, maka $\mathrm{CF}$ penyakit dihitung dengan menggunakan persamaan 2.3:

$\mathrm{CF}_{\text {combine }}=\mathrm{CF}_{\text {old }}+\mathrm{CF}_{\text {gejala }} *\left(1-\mathrm{CF}_{\text {old }}\right)$ Sebagau contoh kasus adalah pemberian nilai $\mathrm{CF}$ pada setiap gejala hingga perolehan persentase keyakinan untuk hama dan penyakit pada tanaman cabai. Perhitungan Manual Untuk Hama Cabai

Kaidah 1:

\begin{tabular}{|l|l|}
\hline I F & $\begin{array}{l}\text { Buah cabai berwarna kuning } \\
\text { pucat dan layu }\end{array}$ \\
\hline AND & $\begin{array}{l}\text { Terdapat titik hitam pada } \\
\text { pangkal buah cabai }\end{array}$ \\
\hline AND & $\begin{array}{l}\text { Buah cabai menjadi busuk } \\
\text { lunak dan berguguran }\end{array}$ \\
\hline THEN & Lalat Buah \\
\hline
\end{tabular}

Langkah pertama, pakar menetukan nilai $\mathrm{CF}$ untuk masingmasing gejala.

Adapun nilai $\mathrm{CF}$ yang diberikan pakar misalnya:

\begin{tabular}{|l|l|l|}
\hline $\begin{array}{l}\text { CF } \\
\text { pakar } \\
\text { (Gejala 1) }\end{array}$ & $=0.7$ \\
\hline $\begin{array}{l}\text { CF pakar } \\
\text { (Gejala 2) }\end{array}$ & $=0.8$ \\
\hline
\end{tabular}




\begin{tabular}{|l|l|l|}
\hline $\begin{array}{l}\text { CF } \\
\text { (Gakar } \\
\text { Gejala 3) }\end{array}$ & $=0.9$ \\
\hline
\end{tabular}

Misalkan user memilih jawaban sebagai berikut :

Kaidah awal (kaidah 1) yang memiliki 3 gejala di pecah menjadi kaidah yang memiliki gejala tunggal, sehingga menjadi :

Proses perhitungan manual untuk kaidah 1.1 :

$$
\begin{aligned}
\mathrm{CF}_{\text {gejala1 }} & =\mathrm{CF}(\text { user }) * \mathrm{CF}(\text { pakar }) \\
& =0.4 * 0.7 \\
& =0,280
\end{aligned}
$$

Proses perhitungan manual untuk kaidah 1.2 :

$$
\begin{aligned}
\mathrm{CF}_{\text {gejala2 }} & =\mathrm{CF}(\text { user }) * \mathrm{CF}(\text { pakar }) \\
& =\mathbf{0 . 8} * \mathbf{0 . 8} \\
& =\mathbf{0 , 6 4 0}
\end{aligned}
$$

Proses perhitungan manual untuk kaidah 1.3 :

$$
\begin{aligned}
\mathrm{CF}_{\text {gejala3 }} & =\mathrm{CF}(\text { user }) * \mathrm{CF} \text { (pakar) } \\
& =\mathbf{1 . 0} 0 \mathbf{0 . 9} \\
& =\mathbf{0 , 9 0 0}
\end{aligned}
$$

Dikarenakan terdapat lebih dari satu gejala, maka untuk menentukan CF hama selanjutnya digunakan persamaan :

$\mathrm{CF}_{\text {combine1 }}\left(\mathrm{CF}_{\text {gejala1, }} \mathrm{CF}_{\text {gejala2 }}\right)=\mathrm{CF}$ gejala1 + CF gejala2*(1- CF gejala1 )

$0.640 *(1-0.280)$

$\mathrm{CF}_{\text {old1 }}=0.662 \mathrm{CF}$ combine2 $(\mathrm{CF}$ old1, $\left.\mathrm{CF}_{\text {gejala3 }}\right)=\mathrm{CF}$ old1 $+\mathrm{CF}$ gejala3 $*$ (1- $\mathrm{CF}$ old1 )

$$
\begin{aligned}
& =0.662+0.900 *(1-0.662) \\
& \mathrm{CF}_{\text {old2 }} \\
& =0.528
\end{aligned}
$$

Keterangan $\mathrm{CF}_{\text {old }}$ terakhir merupakan $\mathrm{CF}_{\text {Hama }}$, berdasarkan hasil perhitungan CF diatas, maka CF hama adalah 0.528. selanjutnnya hitung persentase keyakinan terhadap penyakit dengan persamaan :

$$
\begin{aligned}
\text { Persentase } & =\text { CF Hama }_{\text {H100 }} \\
& =0.528 * 100 \\
& =52.8 \%
\end{aligned}
$$

Berdasarkan hasil perhitungan, maka

\section{Kaidah 1.1:}

IF Buah cabai berwarna kuning pucat dan layu THEN Lalat Buah

Kaidah 1.2:

IF Terdapat titik hitam pada pangkal buah cabai

THEN Lalat Buah

\section{Kaidah 1.3:}

IF Buah cabai menjadi busuk lunak dan berguguran

THEN Lalat Buah

persentase tingkat keyakinan

berdasarkan tabel interpretasi adalah $52.8 \%$

\section{HASIL DAN PEMBAHASAN \\ 4.1 Diagram Konteks}

Untuk menggambarkan arus data pada sistem yang dubangun maka dugunakan Data konteks diagram dengan level 0. Untuk membantu memahami sistem adapun DFD sistem dapat dilihat pada Gambar 2 
dengan data yang di input oleh admin maka sistem akan menampilkan hasil.

Langkah yang digunakan metode Certainty Factor dalam memproses gejalagejala berdasarkan diagnose hama dan penyakit menggunakan metode forward chaining proses analisis certainty factor untuk kaidah dengan premis/gejala tunggal. Formula dasar digunakan apabila belum ada nilai $C F$ untuk setiap gejala yang memberikan diagnosa. Untuk mendapatkan nilai $C F$ penguna dapat memilih dari 15 gejala hama dan 15 gejala penyakit, pada tanaman cabai yang ada dan memberi nilai bobot yang sesuai dengan gejala yang dialami oleh pengguna. Selanjutnya bobot nilai yang diberikan pengguna akan dikalikan dengan bobot nilai yang diberikan oleh pakar. Contoh poses memperoleh nilai $C F$ dengan menggunakan tabel rule, nilai bobot pengguna dan nilai bobot pakar

$$
\mathrm{CF}_{\text {gejala1 }}=\mathrm{CF}(\text { user }) * \mathrm{CF}(\text { pakar })
$$

\section{$0.4 * 0.7$ \\ 0,280}$$
=
$$

$$
\begin{aligned}
\mathrm{CF}_{\text {gejala2 }} & =\mathrm{CF}(\text { user }) * \mathrm{CF}(\text { pakar }) \\
& =0.2 * 0.8 \\
& =0,160 \\
\mathrm{CF}_{\text {gejala3 }} & =\mathrm{CF}(\text { user }) * \mathrm{CF}(\text { pakar }) \\
& =1.0 * 0.9 \\
& =0,900
\end{aligned}
$$

Dikarenakan terdapat lebih dari satu gejala, maka untuk menentukan $\mathrm{CF}$ penyakit selanjutnya digunakan persamaan :

$$
\begin{aligned}
& \mathrm{CF}_{\text {combine1 }}\left(\mathrm{CF}_{\text {gejala1 } 1}, \mathrm{CF}_{\text {gejala2 }}\right)=\mathrm{CF} \text { gejala1 } \\
& +\mathrm{CF} \text { gejala2*(1- CF gejala1 }) \\
& =0.280+0.160 *(1-0.280) \\
& \mathrm{CF}_{\text {old1 }}=0.317 \\
& \mathrm{CF}_{\text {combine2 }}\left(\mathrm{CF}_{\text {old1 } 1}, \mathrm{CF}_{\text {gejala3 }}\right)=\mathrm{CF}_{\text {old1 }}+ \\
& \left.\mathrm{CF}_{\text {gejala3 }} * \text { (1- } \mathbf{C F} \text { old1 }\right) \\
& =0.317+0.900 *(1-0.317) \\
& \mathrm{CF}_{\text {old } 2}=0.831
\end{aligned}
$$

Keterangan $\mathrm{CF}_{\text {old }}$ terakhir merupakan $\mathrm{CF}_{\text {Penyakit, berdasarkan hasil perhitungan } \mathrm{CF}}$ diatas, maka $\mathrm{CF}$ penyakit adalah 0.831 . selanjutnnya hitung persentase keyakinan terhadap penyakit dengan persamaan :

$$
\begin{aligned}
& \text { Persentase } \\
& =\mathrm{CF}_{\text {Penyakit }} * 100 \\
& =0.831 * 100 \\
& =83.1 \%
\end{aligned}
$$

Berdasarkan hasil perhitungan, maka keterangan tingkat keyakinan berdasarkan tabel interpretasi dari pakar dan persentase akhir adalah SANGAT MUNGKIN.

\subsection{User Interface Program}

1 Halaman Utama

Halaman utama merupakan halaman yang pertama kalai tampil ketika pengguna megakses halaman sistem pakar diagnosa penyakit pada tanaman cabai dapat dilihat pada gambar 3

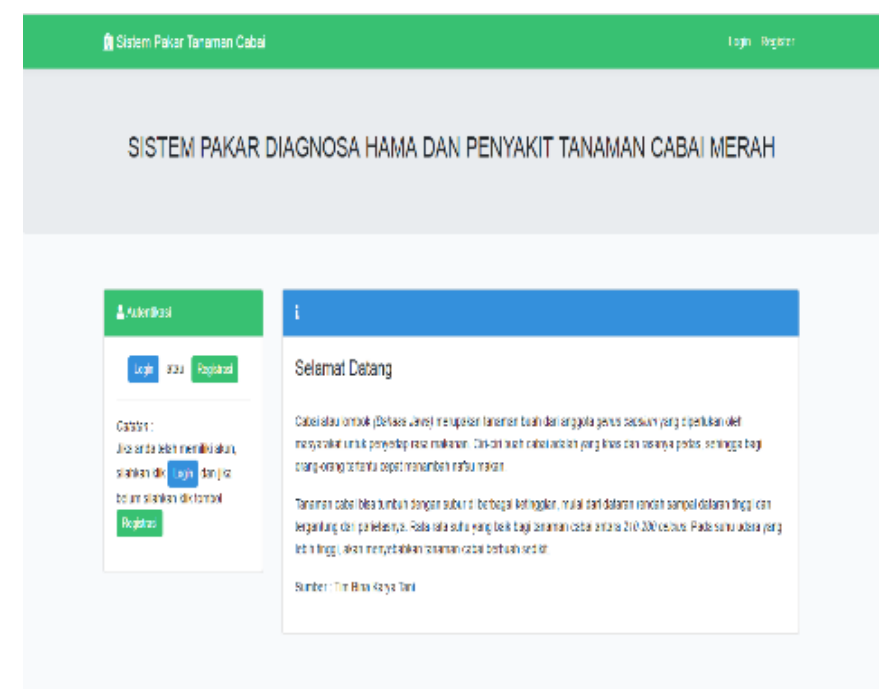

Gambar 3. Halaman utama

2 Halaman Login Admin

From login administrator digunakan untuk melakukan login para administrator untuk masuk ke halaman utama aplikasi. Tampilan from login admin dapat dilihat pada gambar 4. berikut : 


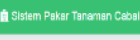

SISTEM PAKAR DIAGNOSA HAMA DAN PENYAKIT TANAMAN CABAI MERAH

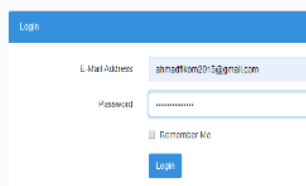

Gambar 4. From Login Administrator

3 Halama Utama Administrator

Halaman utama administrator merupakan halaman utama pada bagian administrator untuk melakukan semua kegiatan dalam sistem. Tampilannya seperti pada gambar 5 . berikut :

SISTEM PAKAR DIAGNOSA HAMA DAN PENYAKIT TANAMAN CABAI MERAH

Gambar 5. Halaman Utama Administrator

4 From Input Data Penyakit

From Input data penyakit digunakan untuk menginputkan data penyakit dan untuk menampilkan penyakit. Tampilannya seperti pada gambar 6 berikut:

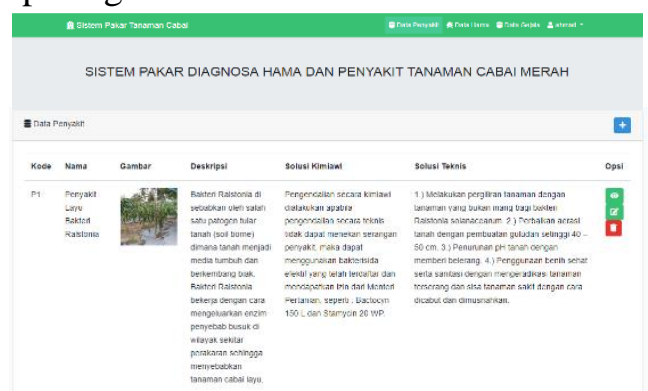

Gambar 6. From Data Penyakit
5 From Input Data Hama

From Input data hama digunakan untuk menginputkan data penyakit dan untuk menampilkan penyakit. Tampilannya seperti pada gambar 4.12. berikut :

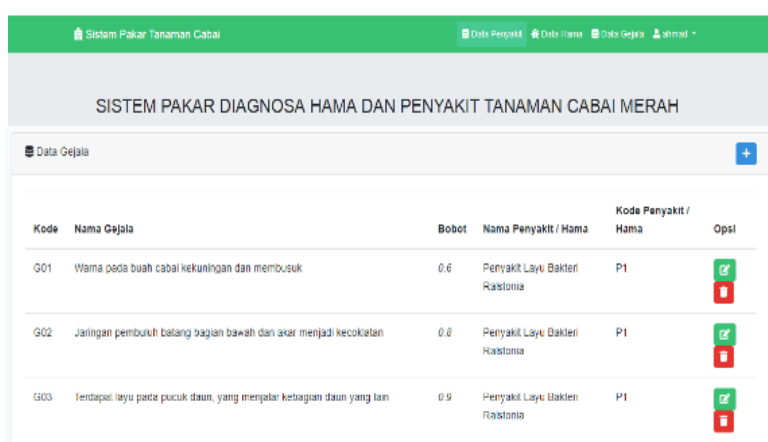

Gambar 7. From Data Hama

\section{From Input Data Gejala}

From input data gejala digunakan untuk menginput gejala hama dan penyakit pada tanaman cabai. Tampilannya seperti pada gambar 8 berikut:

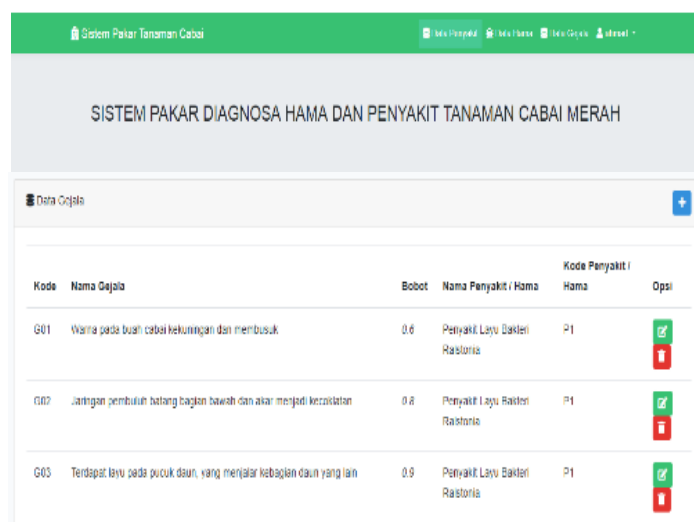

Gambar 8. From Input Data Gejala

\section{From Registrasi User}

Form registrasi user digunakan untuk melakukan registrasi bagi user pengguna aplikasi. Adapun tampilannya dapat dilihat pada gambar 9. berikut : 
SISTEM PAKAR DIAGNOSA HAMA DAN PENYAKIT TANAMAN CABAI MERAH

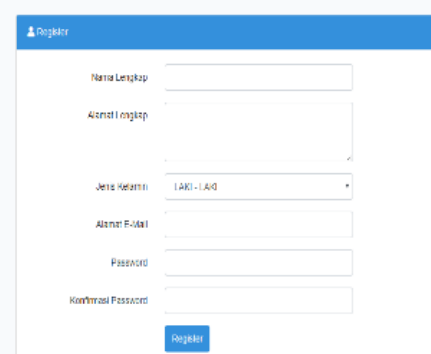

Gambar 9. From Registrasi User

8 From Diagnosa Penyakit

Form diagnosa penyakit digunakan untuk memilih penyakit yang diderita oleh Petani untuk melakukan proses diagnosa dan mendapatkan hasil. Adapun tampilannya dapat dilihat pada gambar 4.15. berikut :

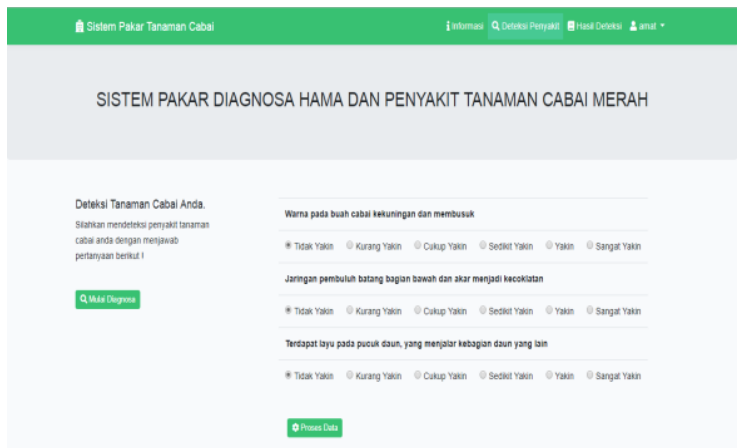

Gambar 10. From Diagnosa Penyakit User

9 Halaman Hasil Proses Diagnosa

Halaman hasil digunakan untuk menampilkan hasil dari proses diagnosa hama dan penyakit pada tanaman cabai. Adapun tampilaannya dapat dilihat seperti gambar 4.16. berikut :

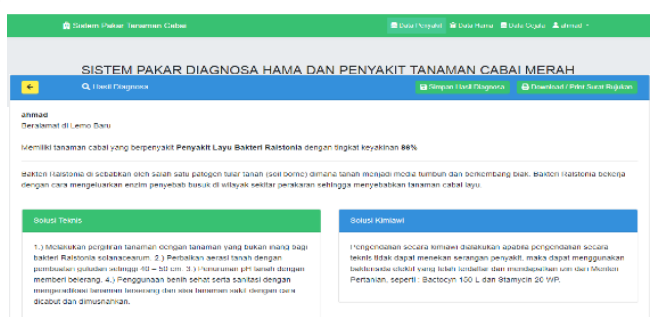

Gambar 11. Halaman Hasil Proses Diagnosa User

\section{KESIMPULAN}

Sebagai kesimpulan dari hasil penelitian ini sebagai berikut:

1. Sistem ini dibangun untuk menyimpan keahliah seorang pakar hama dan penyakit pada tanaman cabai, sehingga sistem ini dapat dijadikan asisten pandai dibidang pertanian sebagai sumber pengetahuan user.

2. Metode Forward Chaining dan Certanty Factor dapat memberikan diagnosa hama dan penyakit pada tanaman cabai berdasarkan gejalagejala yang diberikan. Berdasarkan hasil perhitungan, maka keterangan tingkat keyakinan berdasarkan tabel interpretasi dari pakar dan persentase akhir sebesar 83,1\% adalah Sangat Mungkin kedua metode ini diterapkan untuk menyelesaikan masalah yang ada.

3. Aplikasi sistem pakar ini dapat digunakan untuk mempercepat pencarian dan pengaksesan pada ilmu pengetahuan oleh masyarakat atau orang-orang yang membutuhkan informasi mengenai hama dan penyakit pada tanaman cabai. Sehingga tidak perlu menunggu penyuluh untuk memberikan penyuluhan.

\section{SARAN}

Setelah dilakukan pengujian dan implementasi pada perangkat lunak sistem pakar yang telah dirancang, masih banyak kekurangan dan kelemahan sehingga masih perlu dikembangkan lagi agar kinerja sistem ini lebih baik, untuk itu disarankan :

1. Dengan kemajuan teknologi yang semakin berkembang kiranya aplikasi ini dikembangkan dengan pemrograman lain seperti Android, untuk lebih mempermuda user .

2. Hama dan Penyakit yang dibahas dalam sistem pakar ini dibatasi yaitu, hama lima dan penyakit lima untuk itu 
kedepannya diharapkan dapat ditambahkan lagi data gejala hama dan penyakit serta pengetahuan kepakaran agar dapat digunakan lebih luas.

3. Diharapkan dikembangkan dengan penggunaan pengenalan pola gejala hama dan penyakit dengan menggunakan fitur bentuk sebagai ekstraksi ciri dan klasifikasi City Block Distance.

4. Selain itu sistem pakar dapat menjadi referensi perbandingan untuk sistem pakar lainnya. Program aplikasi sistem pakar dapat dikembangkan tampilannya, sehingga lebih menarik bagi pengguna

\section{DAFTAR PUSTAKA}

[1] W. Kaswidjanti, "Implementasi Mesin Inferensi Fuzzy (Studi Kasus Sistem Pakar Untuk Mendiagnosa Penyakit Tanaman Cabe Merah)," Telematika, vol. 7, no. 2, 2015, doi: 10.31315/telematika.v7i2.424.

[2] T. W. Y. R. W. U. Sri Hariyati Fitriasih, "Sistem Pakar Diagnosa Hama Dan Penyakit Tanaman Cabai Besar Menggunakan Metode Certainty Factor," J. Ilm. SINUS, vol. 15, no. 2, pp. 13-24, 2017, doi: 10.30646/sinus.v15i2.302.

[3] E. H. Wijaya and N. Hidayat, "Diagnosis Penyakit Cabai Dengan Menggunakan Metode Forward Chaining - Dempster-Shafer," $J$. Pengemb. Teknol. Inf. Dan Ilmu Komput., vol. 2, no. 12, pp. 7202-, 2020, [Online]. Available: http://jptiik.ub.ac.id/index.php/jptiik/article/view/3870.

[4] M. Fergusson et al., "PERANCANGAN SISTEM PAKAR UNTUK DIAGNOSA KERUSAKAN HARDWARE LAPTOP MENGGUNAKAN
METODE CERTAINTY FACTOR Bhaskara," J. Chem. Inf. Model., vol. 53, no. 9, pp. 1689-1699, 2013.

[5] A. E. P. Ali Mahmudi, Moh. Miftakhur Rokhman, "Rancang Bangun Sistem Pakar untuk Mendiagnosis Tanaman Cabai Menggunakan Metode Bayes," $J$. Rekayasa Dan Manaj. Sist. Inf., vol. 2, no. 2, pp. 48-58, 2016.

[6] Y. A. Pratama and E. Junianto, "Sistem Pakar Diagnosa Penyakit Ginjal Dan Saluran Kemih Dengan Metode Breadth First Search," J. Inform., vol. 2, no. 1, 2016, doi: 10.31311/ji.v2i1.69.

[7] P. K. Handayani, "Diagnosa Penyakit Jantung Dengan Metode Penelusuran Forward ChainningDepth First Search," Semin. Nas. Inform. 2012 (semnasIF 2012), vol. 2012, no. Sistem Pakar, pp. C-92-C99, 2012.

[8] M. Rizal and F. Putra, "Rancang Bangun Sistem Pakar untuk Diagnosa Hama Tanaman Cabai," Univ. Muhammadiyah Sidoarjo, 2018.

[9] K. E. Setyaputri and A. Fadlil, "Analisis Metode Certainty Factor pada Sistem Pakar Diagnosa Penyakit THT," J. Tek. Elektro Vol. 10 No. 1 , vol. 10 , no. 1 , pp. 30-35, 2018. 